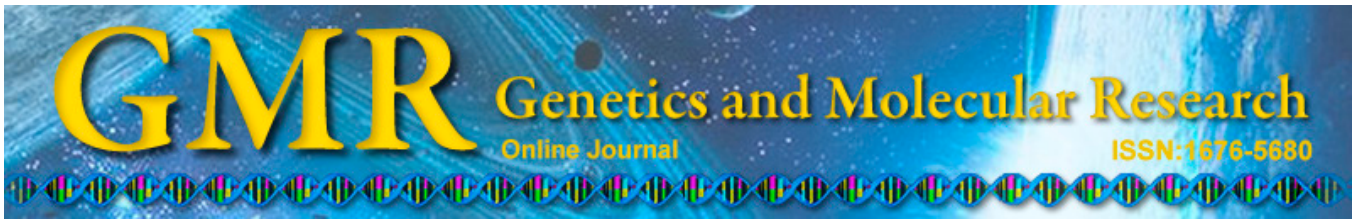

\title{
A simple, fast, and inexpensive CTAB-PVP-silica based method for genomic DNA isolation from single, small insect larvae and pupae
}

\author{
W. Huanca-Mamani, D. Rivera-Cabello and J. Maita-Maita \\ Laboratorio de Biología Molecular de Plantas, \\ Departamento de Producción Agrícola, Facultad de Ciencias Agronómicas, \\ Universidad de Tarapacá, Arica, Chile \\ Corresponding author: W. Huanca-Mamani \\ E-mail:whuanca@uta.cl
}

Genet. Mol. Res. 14 (3): 8001-8007 (2015)

Received October 30, 2014

Accepted April 28, 2015

Published July 17, 2015

DOI http://dx.doi.org/10.4238/2015.July.17.8

\begin{abstract}
In this study, we report a modified CTAB-PVP method combined with silicon dioxide (silica) treatment for the extraction of high quality genomic DNA from a single larva or pupa. This method efficiently obtains DNA from small specimens, which is difficult and challenging because of the small amount of starting tissue. Maceration with liquid nitrogen, phenol treatment, and the ethanol precipitation step are eliminated using this methodology. The $\mathrm{A}_{260} / \mathrm{A}_{280}$ absorbance ratios of the isolated DNA were approximately 1.8, suggesting that the DNA is pure and can be used for further molecular analysis. The quality of the isolated DNA permits molecular applications and represents a fast, cheap, and effective alternative method for laboratories with low budgets.
\end{abstract}

Key words: Genomic insect DNA extraction; Larva and pupa; CTAB-PVP-silica based method 


\section{INTRODUCTION}

Insects are the most diverse of all animal groups, but the larval stages are unknown in most species. Research on larvae is important from an ecological and taxonomic point of view. From an ecological viewpoint, the determination of larval stages is indispensable to estimate the functional role of a species in an ecosystem (Klimes and Saska, 2010) and from a taxonomic standpoint, larval morphology provides valuable phylogenic information that cannot be obtained from adult morphology (Beutel and Leschen, 2005).

Molecular markers, such as random amplified polymorphic DNA (RAPD), single sequence repeats (SSR), and amplified fragment length polymorphism (AFLP), have allowed the genetic characterization of different populations of insects (Chen et al., 2008; Gupta and Preet, 2012). Novel DNA barcoding-based methods are available for identifying the species of insect larvae (Dittrich-Schroder et al., 2012). DNA from unidentified larval samples collected from the field is compared with identified adult samples (Vargas et al., 2014). This methodology has allowed determination of previously unknown morphological and ecological traits of many species during their larval stages (Hayashi and Sota, 2010). Isolation of high quality DNA is an essential prerequisite for any PCR-based molecular tool, and the ability to prepare and isolate genomic DNA from several sources is an important step in many molecular techniques.

Homemade insect DNA isolation methods are cheap and very efficient at producing DNA samples, but are usually time-consuming and less efficient in the removal of protein, carbohydrates, and other organic contaminants from samples, thus, causing enzymatic inhibition in subsequent molecular analyses (Hajibabaei et al., 2005; Chen et al., 2010). Commercial kits are generally very fast but very expensive, and generate large quantities of contaminant wastes such as beads, filters, columns, and microcentrifuge tubes.

Recently, several methodologies to isolate genomic DNA from adult insects have been reported (Chen et al., 2008; Gupta and Preet, 2012; Wang and Wang, 2012). Although there are few reports about genomic DNA isolation from larvae and pupae (Dittrich-Schroder et al., 2012), there are fewer reports related to obtaining sufficient quantities of high-quality DNA for molecular work when the larvae or pupae are very small.

In this study, we develop a new method to obtain good quality DNA from larvae and pupae, including single and very small specimens. This method combines CTAB-PVP-extraction and silicon dioxide (silica)-based protocols. Our method is rapid, simple, inexpensive, efficient, and less hazardous to health than other methods described previously.

\section{MATERIAL AND METHODS}

\section{Insect material}

Larvae and pupae of Angelabella tecomae and Macaria mirthae were donated by the Laboratorio de Entomología of the Universidad de Tarapacá, Arica, Chile. These samples were preserved in $95 \%$ ethanol.

\section{DNA extraction protocol}

For DNA isolation, entire larva or pupa were transferred to a $1.5 \mathrm{~mL}$ centrifuge tube, ground using a plastic pestle, and immediately mixed with $500 \mu \mathrm{L}$ lysis buffer $(2 \% \mathrm{CTAB}, 100$ 
$\mathrm{mM}$ Tris- $\mathrm{HCl}, 1.4 \mathrm{M} \mathrm{NaCl}, 1 \% \mathrm{PVP}, 20 \mathrm{mM}$ disodium salt of ethylenediaminetetraacetic acid $\left(\mathrm{Na}_{2} \mathrm{EDTA}\right), 0.2 \% \mathrm{LiCl}$. The $\mathrm{pH}$ was adjusted to 8.0 before autoclaving. After vortexing and incubating at $65^{\circ} \mathrm{C}$ for at least $30 \mathrm{~min}$ (gently shaken every $10 \mathrm{~min}$ ), the mixture was centrifuged at 10,000 rpm for $5 \mathrm{~min}$ at room temperature (RT). The supernatant was transferred into a new $1.5 \mathrm{~mL}$ centrifuge tube and an equal volume of chloroform-isoamyl alcohol $(24: 1 \mathrm{v} / \mathrm{v})$ was added. Then, the tube was gently flipped several times. After centrifugation for $10 \mathrm{~min}$ at $12,000 \mathrm{rpm}$, the supernatant was transferred into a new $1.5 \mathrm{~mL}$ centrifuge tube, followed by the addition of 1 volume of $3 \mathrm{M} \mathrm{NaCl}$ and $25 \mu \mathrm{L}$ silica matrix $(1 \mathrm{mg} / \mathrm{mL})$. The mixture was vortexed and incubated for $5 \mathrm{~min}$ at RT and then centrifuged at $12,000 \mathrm{rpm}$ for $11 \mathrm{~s}$. The pellet was washed twice with $500 \mu \mathrm{L}$ washing solution $(50 \%$ ethanol, $10 \mathrm{mM}$ Tris- $\mathrm{HCl}, \mathrm{pH} 7.5,100$ $\mathrm{mM} \mathrm{NaCl}, 1 \mathrm{mM}$ EDTA). DNA was eluted by re-suspending the silica matrix pellet with 50 and $28 \mu \mathrm{L}$ of distillated deionized $\mathrm{H}_{2} \mathrm{O}$ for M. mirthae and A. tecomae, respectively, and then incubated at $65^{\circ} \mathrm{C}$ for $5 \mathrm{~min}$ and centrifuged at 12,000 rpm for $2 \mathrm{~min}$ at RT. Approximately 45 and $25 \mu \mathrm{L}$ supernatant containing the eluted DNA from M. mirthae and A. tecomae, respectively, were carefully transferred to new tubes without disturbing the silica particles.

\section{Preparation of silica matrix}

The procedure to prepare the size-fractioned silica particles was undertaken according to Li et al. (2010). Silicon dioxide (5 g; S5631, Sigma-Aldrich, Saint Louis, MO, USA) was mixed with $50 \mathrm{~mL}$ sterile water in a $50 \mathrm{~mL}$ Falcon tube and allowed to settle overnight. The supernatant containing fine silica particles was removed and the pellet was re-suspended in $50 \mathrm{~mL}$ sterile water and re-settled overnight. The supernatant was removed and the pellet was re-suspended in $50 \mathrm{~mL}$ sterile water.

\section{DNA amplification and sequencing reactions}

Polymerase chain reaction (PCR) was carried out using the universal barcoding primers LepF (5'-ATTCAACCAATCATAAAGATATTGG-3') and LepR (5'-TAAACTTCTGGATGT CCAAAAAATCA-3') (Hebert et al., 2004) to yield an approximately 690-bp fragment of the cytochrome oxidase subunit I (COI) region of the mitochondrial DNA. PCR was performed in a final volume of $20 \mu \mathrm{L}$. Each reaction contained $1 \mu \mathrm{L}$ DNA extract, 10 pmoles of each primer, $2.5 \mathrm{mM}$ of each dNTP, $2 \mathrm{mM} \mathrm{MgCl}$, 1 X PCR buffer $(\mathrm{KCl}), 1$ unit of Taq DNA polymerase (Thermo Scientific) and sterile distilled water. Cycling conditions were: $5 \mathrm{~min}$ at $94^{\circ} \mathrm{C} ; 35$ cycles of $30 \mathrm{~s}$ at $94^{\circ} \mathrm{C} ; 30 \mathrm{~s}$ at $55^{\circ} \mathrm{C} ; 30 \mathrm{~s}$ at $72^{\circ} \mathrm{C}$, and a final elongation step of $2 \mathrm{~min}$ at $72^{\circ} \mathrm{C}$. PCR blank controls were incorporated. PCR products ( $3 \mu \mathrm{L}$ of each) were visualized on $1.5 \%$ agarose gels stained with gel-red (Biotium). Reactions containing fragments of the expected size were directly sequenced by a commercial facility (Macrogen, South Korea).

\section{RESULTS}

We tested this method with larvae and pupae from A. tecomae and M. mirthae (Figure 1).

The integrity of the genomic DNA isolated using this method was visualized on $1.2 \%$ agarose gels (Figure 2A). DNA samples showed intact/clear bands on agarose gels, suggesting that little or no DNA degradation had occurred during the extraction (Figure 2A). Spectrophotometer analysis showed that the $\mathrm{A}_{260} / \mathrm{A}_{280}$ ratios of DNA samples ranged from 1.66 to $1.94(\mathrm{~N}$ 
=7) and 1.62 to $1.93(\mathrm{~N}=6)$ for M. mirthae and A. tecomae, respectively, suggesting that the DNA fraction was pure and may be used for further analysis. In all samples, the $\mathrm{A}_{260} / \mathrm{A}_{230} \mathrm{ra}-$ tios were greater than 1.6, suggesting minimum contamination by polysaccharides. The yields were 300 and $156 \mathrm{ng} / \mu \mathrm{L}$ for M. mirthae and A. tecomae, respectively.

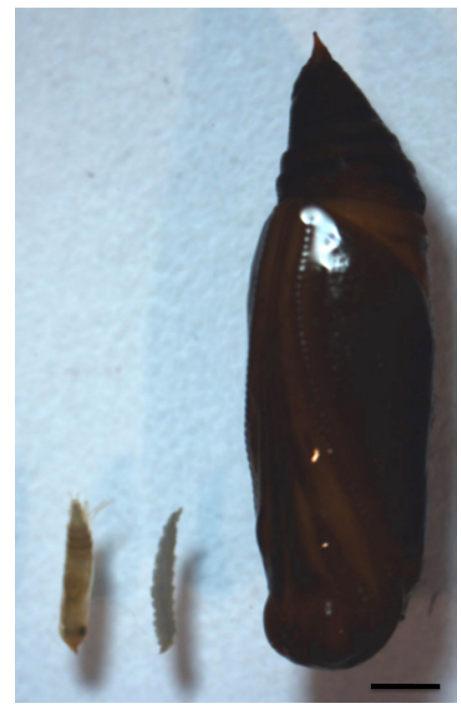

Figure 1. Pupa and larva of Angelabella tecomae (left) and pupa of Macaria mirthae (right). Scale bar: $1 \mathrm{~mm}$.

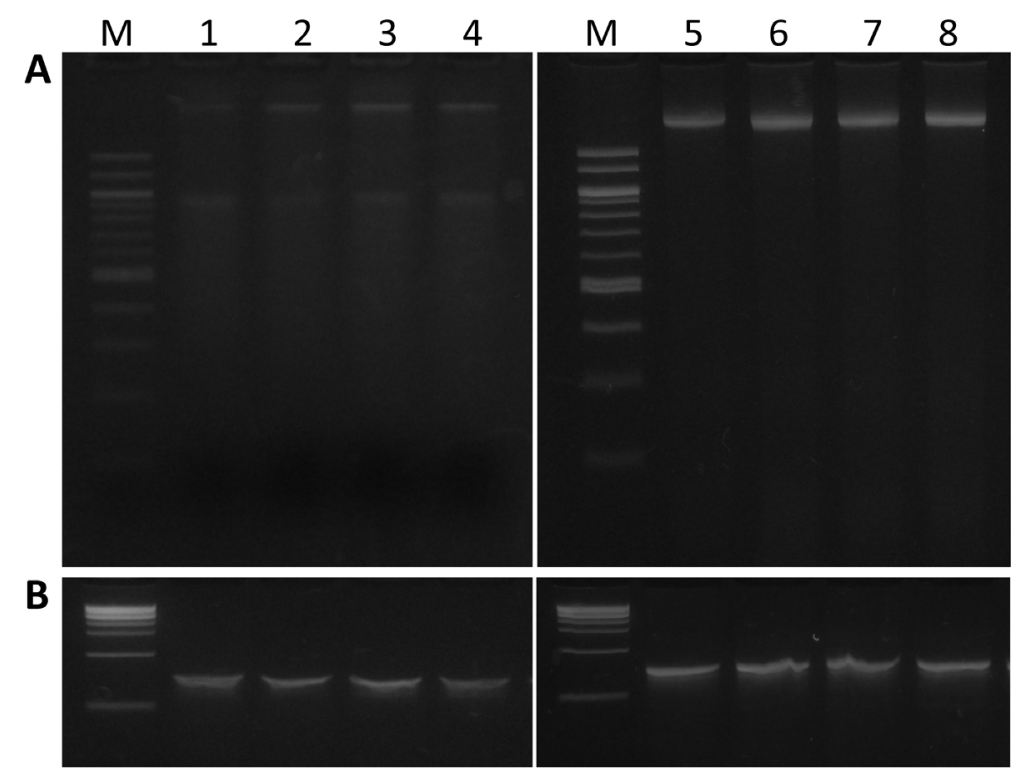

Figure 2. Total genomic DNA analysis (A) and amplification of the cytochrome oxidase subunit I gene fragment (B) using total genomic DNA extracted from larvae and pupae of Angelabella tecomae (1-4) and Macaria mirthae (5-8) with the CTAB-PVP-silica method. Samples 1, 2, 5, and 6 correspond to genomic DNA from a single larva and samples 3, 4, 7, and 8 correspond to genomic DNA from a single pupa. Lane $M=100-\mathrm{bp}$ (A) or 1-kb DNA ladder (B). 
The quality of the genomic DNA isolated using this method and its usefulness for basic molecular analysis was evaluated by PCR. A single fragment of approximately $690 \mathrm{bp}$ of COI was successfully amplified in all samples analyzed (Figure 2B). These PCR products generally yielded sequence read lengths of 690 bp during DNA sequencing analysis (Figure 3 ), which also reflects the high quality of the DNA template generated by this method.

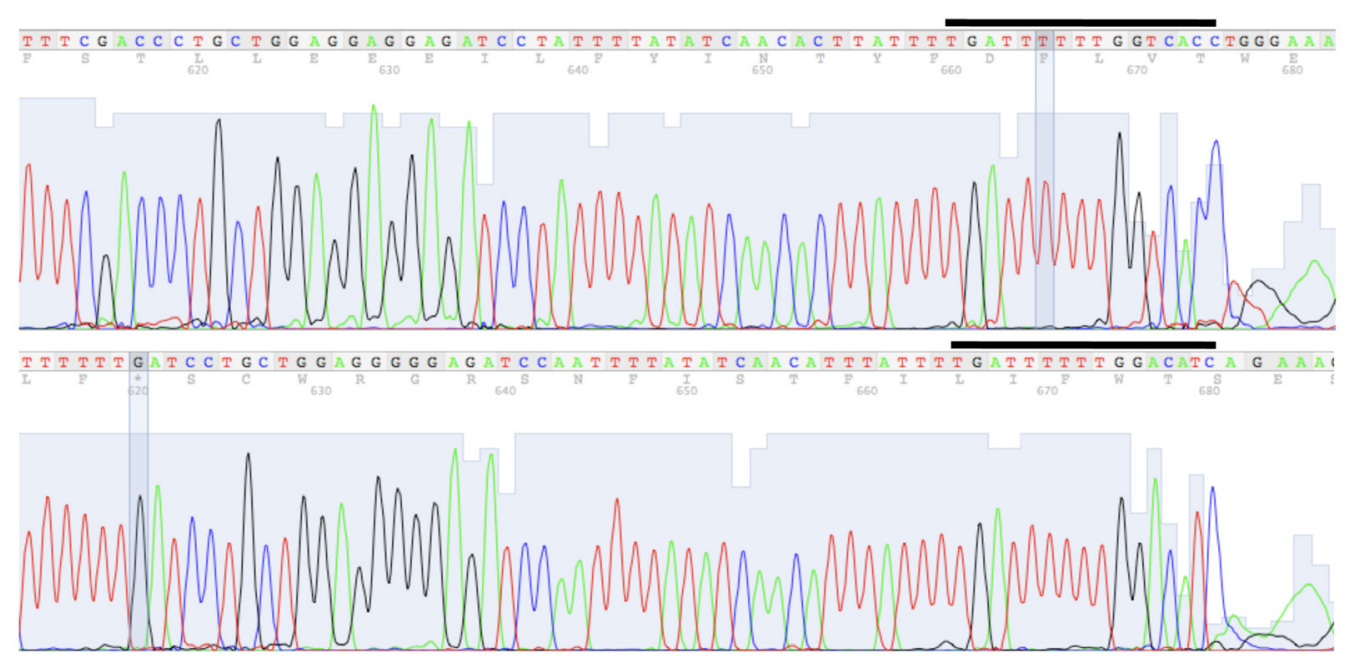

Figure 3. DNA sequencing of the cytochrome oxidase subunit I region in Macaria mirthae (upper panel) and Angelabella tecomae (lower panel). The 3'-end of each DNA sequencing result is shown with individual nucleotide peaks clearly distinguishable. Fragments of the primer sequence are indicated by a black line.

\section{DISCUSSION}

A simple and efficient protocol for genomic DNA extraction is of great scientific value for a wide range of applications. In this study, we developed and evaluated the effectiveness of a simple, fast, and low-cost procedure to successfully extract genomic DNA from larvae and pupae, including small samples. We choose A. tecomae because its larvae and pupae are around $1.5 \mathrm{~mm}$ in length (Figure 1), and thus, represent a good system to demonstrate the effectiveness of this method. The CTAB-PVP-silica DNA extraction protocol combines the CTAB-PVP method (Atashpaz et al., 2010) and the silica binding procedure (Li et al., 2010). The CTAB-PVP method was previously developed to isolate bacterial genomic DNA and showed excellent results in several genomic DNA extractions of fungi (HuancaMamani et al., 2014). This method does not require liquid nitrogen to grind the samples. The presence of phenolic compounds and polysaccharides can co-precipitate with DNA and inhibit enzymatic reactions in subsequent analyses (Lodhi et al., 1994; Calderón-Cortes et al., 2010). In this method, CTAB and PVP were used to remove these contaminants. CTAB separates the polysaccharides from DNA during extraction (Möller et al., 1992; Lodhi et al., 1994; Rouhibakhsh et al., 2008) and PVP forms complex hydrogen bonds with phenols and co-precipitates with cell debris upon cell lysis (John, 1992; Puchooa and Venkatasamy, 
2005). The RNA is eliminated from samples through selective precipitation using $\mathrm{LiCl}$ present in the lysis buffer. $\beta$-mercaptoethanol is not used because it may be toxic to some extent (Rouhibakhsh et al., 2008).

Due to the ability of DNA to bind to silica in the presence of chaotropic salt (Boom et al., 1990), it has been widely used in DNA isolation, being a very efficient, inexpensive and rapid means to isolate DNA from several sources (Carter and Milton, 1993: Hoss and Paabo, 1993; Lakshmi et al., 1999; Dederich et al., 2002; Li and Sheen, 2010).

Amplifications of the COI fragment were obtained after the DNA samples had been stored for at least eleven months (data not shown), indicating that DNA isolated by the CTABPVP-silica method is suitable for longer storage periods.

The advantage of this method is its low cost. Maceration with liquid nitrogen, phenol treatment, and the ethanol precipitation step are all eliminated using this methodology. All solutions used in this protocol are made from common and inexpensive chemicals. The original protocol used sodium iodide (NaI) as the chaotropic salt to allow binding of DNA to silica (Li et al., 2010), which is an expensive chemical. We replaced it with $\mathrm{NaCl}$, which produced better results than $\mathrm{NaI}$ (Rohland and Hofreiter, 2007) and it is cheaper, so the total cost for 50 reactions is less than US\$ 5 .

In conclusion, this is the first report that uses silica in an insect DNA extraction protocol. This method is an efficient, inexpensive, and highly reproducible technique to isolate total genomic DNA from tissues of larvae or pupae, obtaining a good yield of high-quality DNA, even from very small specimens for several molecular applications, and represents a viable alternative in laboratories with low budgets.

\section{Conflicts of interest}

The authors declare no conflict of interest.

\section{ACKNOWLEDGMENTS}

We thank Dr. Héctor A. Vargas from the Laboratorio de Entomología Vegetal of the Universidad de Tarapacá for donating the insect samples used in this research. Research supported by Convenio de Desempeño UTA-Mesesup-2 and Fondecyt \#11100492.

\section{REFERENCES}

Atashpaz S, Khani S, Barzegari A, Barar J, et al. (2010). A robust universal method for extraction of genomic DNA from bacterial species. Mikrobiologiia 79: 562-566.

Beutel RG and Leschen RAB (2005). Phylogenetic analysis of Staphyliniformia (Coleoptera) based on characters of larvae and adults. Syst. Entomol. 30: 510-548.

Boom R, Sol CJ, Salimans MM, Jansen CL, et al. (1990). Rapid and simple method for purification of nucleic acids. $J$. Clin. Microbiol. 28: 495-503.

Calderón-Cortés N, Quesada M, Cano-Camacho H and Zavala-Páramo G (2010). A simple and rapid method for DNA isolation from Xylophagous insects. Int. J. Mol. Sci. 11: 5056-5064.

Carter MJ and Milton ID (1993). An inexpensive and simple method for DNA purifications on silica particles. Nucleic Acids Res. 21: 1044.

Chen M, Zhu YY, TAO J and Luo YQ (2008). Methodological comparison of DNA extraction from Holcocerrus hippophaecolus (Lepidoptera: Cossidae) for AFLP analysis. For. Stud. China 10: 189-192.

Chen H, Rangasamy M, Tan SY, Wang H, et al. (2010). Evaluation of five methods for total DNA extraction from western 
corn rootworm beetles. PLoS One 5: e11963.

Dederich DA, Okwuonu G, Garner T, Denn A, et al. (2002). Glass bead purification of plasmid template DNA for high throughput sequencing of mammalian genomes. Nucleic Acids Res. 30: e32.

Dittrich-Schroder G, Wingfield MJ, Klein H and Slippers B (2012). DNA extraction techniques for DNA barcoding of minute gall-inhabiting wasps. Mol. Ecol. Resour. 12: 109-115.

Gupta S and Preet S (2012). Protocol optimization for genomic DNA extraction and RAPD-PCR in mosquito larvae (Diptera: Culicidae). Ann. Biol. Res. 3: 1553-1561.

Hajibabaei M, deWaard JR, Ivanova NV, Ratnasingham S, et al. (2005). Critical factors for assembling a high volume of DNA barcodes. Philos. Trans. R. Soc. B-Biol. Sci. 360: 1959-1967.

Hayashi M and Sota T (2010). Identification of elmid larvae (Coleoptera: Elmidae) from Sanin District of Honshu, Japan, based on mitochondrial DNA sequences. Entomol. Sci. 13: 417-424.

Hebert PD, Penton EH, Burns JM, Janzen DH, et al. (2004). Ten species in one: DNA barcoding reveals cryptic species in the neotropical skipper butterfly Astraptes fulgerator. Proc. Natl. Acad. Sci. U. S. A. 101: 14812-14817.

Hoss M and Paabo S (1993). DNA extraction from Pleistocene bones by a silica-based purification method. Nucleic Acids Res. 21: 3913-3914.

Huanca-Mamani W, Martínez RS and Sepúlveda-Chavera G (2014). A fast and efficient method for total DNA extraction from soil filamentous fungi. IDESIA 32: 75-78.

John ME (1992). An efficient method for isolation of RNA and DNA from plants containing polyphenolics. Nucleic Acids Res. 20: 2381.

Klimes P and Saska P (2010). Larval and adult seed consumption affected by the degree of food specialization in Amara (Coleoptera: Carabidae). J. Appl. Entomol. 134: 659-666.

Lakshmi R, Baskar V and Ranga U (1999). Extraction of superior-quality plasmid DNA by a combination of modified alkaline lysis and silica matrix. Anal. Biochem. 272: 109-112.

Li JF, Li L and Sheen J (2010). Protocol: a rapid and economical procedure for purification of plasmid or plant DNA with diverse applications in plant biology. Plant Methods 6: 1.

Lodhi MA, Ye GN, Weeden NF and Reisch BI (1994). A simple and efficient method for DNA extraction from gravepine cultivars and Vitis species. Plant Mol. Biol. Rep. 12: 6-13.

Möller EM, Bahnweg G, Sandermann H and Geiger HH (1992). A simple and efficient protocol for isolation of high molecular weight DNA from filamentous fungi, fruit bodies, and infected plant tissues. Nucleic Acids Res. 20: 61156116.

Puchooa D and Venkatasamy K (2005). A protocol for the isolation of DNA from Trochetia boutoniana. Int. J. Agric. Biol. 7: 82-85.

Rohland N and Hofreiter M (2007). Comparison and optimization of ancient DNA extraction. Biotechniques 42: 343-52.

Rouhibakhsh A, Priya J, Periasamy M, Haq QM, et al. (2008). An improved DNA isolation method and PCR protocol for efficient detection of multicomponents of begomovirus in legumes. J. Virol. Methods 147: 37-42.

Vargas HA, Vargas-Ortiz M, Huanca-Mamani W and Hausmann A (2014). Prey identification in nests of the potter wasp Hypodynerus andeus (Packard) (Hymenoptera, Vespidae, Eumeninae) using DNA barcodes. Rev. Bras. Entomol. 58: $157-160$.

Wang Q and Wang X (2012). Comparison of methods for DNA extraction from a single chironomid for PCR analysis. Pak. J. Zool. 44: 421-426. 